\title{
ДИНАМІКА РЕЦЕПЦЇ̈ ПРОЗИ ДЖЕЙМСА ДЖОЙСА В УКРАЇНІ: СОЦІОКУЛЬТУРНІ УМОВИ ТА ПЕРЕКЛАДАЦЬКІ РІШЕННЯ
}

\author{
Марія Бондаренко \\ Львівський національний університет імені Івана Франка, \\ вул. Університетська, 1, м. Львів, Украӥна, 79000 \\ mariya.bondarenko@lnu.edu.ua
}

\begin{abstract}
У статті проаналізовано рецепцію прозових творів ірландського письменника Джеймса Джойса в Україні у період з 1920-х років до сьогодні. У статті, зокрема, здійснено спробу визначити причини появи або відсутності перекладів творів письменника у певний історичний період, їхній можливий вплив на розвиток модерністської течії в Україні через вивчення загального соціокультурного контексту, аналіз критичних статей, відгуків і перекладацьких коментарів, а також інтерв'ю $з$ перекладачами. Особливу увагу зосереджено на стратегіях відтворення культурно-історичних алюзій та мовних експериментів Джойса в різночасових перекладах оповідань зі збірки “Дублінці”, у двох перекладах роману “Портрет митця замолоду” та есе “Джакомо Джойс". Насамкінець, у статті розглянуто особливості діяльності різних видів перекладацьких тандемів, що працювали з перекладами прозових творів Джойса.

Ключові слова: художній переклад, рецепція, багатомовність, алюзія, Джойс, модернізм, “Дублінці”.
\end{abstract}

Вступ. Експеримент, складність форми та метод потоку свідомості - це перше, 3 чим зазвичай асоціюється ім'я ірландського письменника й поета Джеймса Джойса. Один із флагманів літератури модернізму початку XX століття, Джойс не лише переосмислив формальну й концептуальну структури традиційних прозових жанрів, але й познайомив світову спільноту з життям тогочасної Ірландії, охопленої суспільною кризою, понівеченої багатолітнім культурним і економічним тиском Британської імперії та зануреної в пошуки власної ідентичності.

Прозовим творам митця притаманна композиційна та мовна багатошаровість: інтертекстуальні та інтратекстуальні зв'язки вибудовують композиційний “каркас” його творів, а мовне розмаїття - поєднання англійської, гельської, французької, італійської, латини тощо - слугує їхнім стилістичним обрамленням. Гостра соціальна тематика й мовно-літературний експеримент, втілений у текстах Джойса, донині привертають увагу літературних критиків і перекладачів з усього світу. Станом на 2020 рік українська читацька аудиторія ознайомлена 3 усіма опублікованими

(C) Бондаренко М., 2020 
прозовими творами письменника, за винятком романів “Герой Стівен” і “Поминки за Фіннеганом".

Отже, мета цієї розвідки - проаналізувати основні етапи рецепції прози Джеймса Джойса в Україні з огляду на соціально-історичний контекст. Досягнення мети передбачає виконання таких завдань: 1) дослідити чинники, що сприяли появі повторних перекладів і перевиданню раніше перекладених творів Джойса; 2) простежити способи відтворення мовних експериментів й культурно-історичних алюзій у різночасових українських перекладах творів письменника, здійснених окремими перекладачами та перекладацькими тандемами. Увагу зосереджено на перекладах оповідань збірки “Дублінці”, автобіографічного роману “Портрет митця замолоду” та есе “Джакомо Джойс". Зазначимо, що аналіз історії та особливостей українського перекладу роману "Улісс" (2015), перевиданого у 2018 році, заслуговує на окреме дослідження. Крім того, перекладознавці досі оминали увагою українські переклади творів Джойса початку XX століття. Авторка статті прагне заповнити цю прогалину. Вивчення рецепції творчості письменника не буде повноцінним без урахування метатекстових перекладів його творів - критичних оглядів, статей та відгуків, що публікувалися в різні часи.

Аналіз останніх досліджень i публікацій. Починаючи 3 70-х років ХХ століття відбувся поступовий відхід від лінгвістичної парадигми перекладознавчих досліджень у бік культурно-орієнтованого, а пізніше - міждисциплінарного підходу. Інтерес перекладознавців (Е. Честерман, Г. Турі, С. Басснет, А. Лефевер, Е. Гентцлер) зосередився не так на понятті еквівалентності перекладеного тексту оригіналові й першочерговості останнього, як на культурних, соціальних та історичних умовах рецепції творів іноземної літератури читацькою аудиторією. На перший план виходять особистість перекладача й мотиви, які зумовлювали вибір твору для перекладу й визначення подальшої перекладацької стратегії.

Одночасно відбулася зміна парадигми літературознавчих досліджень - на заміну автора й твору (work) приходять читач і текст (text); змістова структура тексту твориться не автором, а особисто читачем. Погляди герменевтів Г. Я. Яусса, В. Ізера, Г. Г. Гадамера було покладено в основу поняття рецепції, себто сприйняття читачем літературного тексту 3 огляду на власний “горизонт очікування" та його зміни в процесі читання. Зважаючи на те, що горизонт очікування читачів змінюється під впливом різноманітних мовних та позамовних чинників, основу теорії рецепції становить вивчення динаміки рецепції творів читацькою аудиторією в різні історичні періоди [8, с. 262]. Крім того, враження від твору мистецтва має феноменологічний характер: у свідомості та пам'яті читачів він постає не таким, яким він $\epsilon$, а таким, яким він здається [виділення - M. Б.]. Суб'єктивність сприйняття індивідом дійсності як джерело осягнення істини окреслюється концепцією історії впливів (Wirkungsgeschichte), викладеною в праці “Істина і метод” Г. Г. Гадамера. За Гадамером, вона не лише висвітлює, як твір тлумачиться у різні періоди, а й формує сучасну інтерпретацію оригінального тексту: “Коли ми, стоячи на тій історичній дистанції, що обумовлює для нас герменевтичну ситуацію загалом, прагнемо зрозуміти певне історичне явище, ми завжди й одразу опиняємося під впливом історії впливів. Вона 
наперед визначає те, що видається нам сумнівним, і тому перетворюється на предмет вивчення, однак, сприймаючи безпосереднє явище як цілковиту істину, що існує насправді, навіть більше: ми забуваємо повністю істину цього явища як цілого "[1, с. 279].

Водночас перекладознавець Е. Гентцлер наголошує на необхідності діахронічного аналізу перекладів з урахуванням культури, ідеології та мовної ситуації, в яких 3'явилися і оригінальний текст, і переклад [9, viii]. Вивчення паратекстів (інтерв'ю, коментарів і приміток до оригіналів і перекладів) і метатекстів (статей, оглядів і відгуків) визначають історико-культурну орієнтацію сучасних перекладознавчих студій і цієї роботи зокрема.

Дослідження ролі перекладу в культурному та історичному розвитку народу сформувало окремий напрям перекладознавчих досліджень, відомий як історія перекладу. За визначенням Е. Пима, історія перекладу - це набір дискурсів, що зумовлюють зміни або їхню відсутність у сфері перекладу [16, с. 5]. Напрям включає в себе дослідження подій та чинників, що сприяли появі перекладів (або їхній відсутності), а також наслідків, спричинених перекладами (або їхньою відсутністю) [16, с. 11]. Е. Пим окреслює чотири принципи, яких слід дотримуватися під час дослідження у галузі історії перекладу:

1) основу дослідження мають становити соціальні причини (чому переклад було здійснено в певний час та у певному місці?);

2) центральним об'єктом дослідження має бути перекладач, адже соціальні причини напряму пов'язані з людською відповідальністю;

3) необхідним є дослідження соціального контексту, в якому живе та працює перекладач;

4) причини для здійснення дослідження в галузі історії перекладу мають існувати в теперішньому часі [16, с. 3-4].

Рандл К. пропонує інший - протилежний до традиційного - підхід до вивчення історії перекладу. Рандл стверджує, що дослідження історичних наслідків перекладу та історичного контексту, що впливає на переклад і перекладачів - це два різних завдання, виконання яких вимагають різних методів дослідження. Вчений розглядає переклад насамперед як “політичну, культурну, економічну - себто історичну - подію" $[17$, c. 6$]$.

Зважаючи на тяглість історії перекладів прозових творів Джеймса Джойса в Україні, це дослідження грунтується на діахронному підході, а його структуру побудовано на принципах, окреслених Е. Пимом.

Методологія дослідження. В основу дослідження покладено порівняльний перекладознавчий аналіз різночасових перекладів прози Джойса, що дозволить простежити динаміку змін перекладацьких пріоритетів упродовж століття. Згаданий метод використовуватиметься у комбінації з методом лінгвостилістичного аналізу та методом контекстуального аналізу задля дослідження стилістичних особливостей вихідного і цільового текстів і подальшого їх співставлення. Історико-літературний метод використовуватиметься для 3'ясування розвитку літературної епохи та окреслення ролі об'єкта дослідження в загальноісторичному контексті. Метод 
інтерв'ю було використано задля визначення перекладацьких пріоритетів сучасних перекладачів Джойсових текстів.

Результати дослідження та їхнс обгрунтування. Загалом для західноєвропейської та американської аудиторії постать Джеймса Джойса була і досі залишається суперечливою. Джойсів творчий метод став джерелом натхнення і для його сучасників, і для майбутніх поколінь письменників з усього світу: В. Набокова, В. Фолкнера, Х. Кортасара, Е. Гемінгвея, Х. Л. Борхеса та інших. Очевидно, розквіт літератури модернізму в Америці та Західній Європі відбувся не без впливу творчості Джойса, яку вперше було представлено на суд читачів Італії (1916) та Франції (1918) у вигляді двох рецензій на його праці. Згодом з'явилися і повноцінні переклади творів письменника: французький переклад “Портрета митця...” було оприлюднено в 1924 році; збірку “Дублінці” було опубліковано французькою в 1926 році, німецькою - в 1928 [14, с. 9]; повний переклад роману “Улісс” було видано німецькою 1927 року і французькою в 1929. Відгуки перекладачів та критиків були різними. Французький поет і перекладач Валері Ларбо захоплювався Джойсом: “Я в захваті від “Улісса”... Це надзвичайний твір! Нічим не поступається Рабле” [13, с. 362]. 3 іншого боку, італійський перекладач Чезаре Павезе відмовився перекладати "Улісс" італійською, пояснивши це так: “Чесно кажучи, всі твори Джойса мене дратують...Я усім серцем ненавиджу Джойса” [13, с. 339-340]. Можна припустити, що раннє знайомство 3 творчістю Джойса у Західній Європі частково зумовлене особистими вподобаннями та літературними смаками перекладачів, які ніяк не обмежувалися державою.

Прагнення відійти від традиційних селянських мотивів і перейняти найкращі традиції європейської інтелектуальної прози зумовлювали розвиток літературного модернізму в Україні початку XX століття. Проголошений Михайлом Хвильовим курс на "психологічну Європу” - “Свропу грандіозної цивілізації, Європу - Гете, Дарвіна, Байрона, Ньютона, Маркса і т. д. і т. п.” [6, с. 203] фактично не залишав місця для Європи Джойса, Вулф і Пруста - зневіреної та паралізованої наслідками війни. Надмірна “анатомічність”, відвертість і деяка брутальність Джойсового стилю перетворювали Європу радше на антивзірець. Саме тому постать Джойса цікавила не стільки модерністів, скільки представників соцреалізму, які перетворили творчість письменника на інструмент пропаганди. Першою україномовною згадкою про доробок Джойса стала критична рецензія літературознавця Олександра Ляйтеса на роман "Улісс", опублікована на сторінках "Культури і побуту" - додатку до газети “Вісті ВУЦВК”, що слугувала майданчиком для пропаганди соцреалізму. Помилково називаючи Лондон місцем розвитку подій у романі, Ляйтес доволі нейтрально характеризує гротескність творчого методу Джойса - опис одного дня із життя пересічної маленької людини, поданий із фотографічною точністю. Утім, стаття головно акцентувала увагу на образі знудженої Свропи, в якій більше не було місця “великій” - не бурлескній - літературі.

Українські літератори, що проживали на теренах заходу України (спочатку в складі Австро-Угорщини, а згодом - Польщі), мали більше простору для творчості. Завдяки географічній і культурній близькості до європейських країн, українська читацька спільнота Галичини безпосередньо познайомилася 3 доробком Джойса 
раніше за своїх співвітчизників із Наддніпрянщини. Зокрема, польська дослідниця Йоланта Вавжицка зазначає, що німецькомовний примірник роману “Улісс" зберігався в громадській бібліотеці Львова та був доступний для читачів [13, с. 220].

Переклад оповідання "Пансіон при родині" (“The Boarding House") зі збірки “Дублінці”, що змальовувала життя пересічних ірландців XX століття, ознаменував початок української джойсіани. Твір було опубліковано в літературному часописі "Вікна" в 1928 році. Ім'я перекладача зазначено не було. У 1933 році вийшов друком переклад оповідання "Евеліна" (“Eveline”), опублікований у літературному журналі “Дзвони”. Публікація супроводжувалася коротким коментарем перекладача Івана Черкавського, який провів паралель між стилем Джойса та стилем Василя Стефаника. Цікаво, що обидва видання мали різне ідеологічне спрямування: часопис "Вікна", ініційований західноукраїнським осередком комуністичної партії, переважно публікував твори “пролетарських" письменників; журнал “Дзвони” натомість мав католицьке спрямування, а Йосип Сліпий очолював його редакційну комісію.

У 1936 році було оприлюднено повторний переклад оповідання “Евеліна" на сторінках газети “Новий Час". Ім'я перекладача було подано в скороченій формі М. С-ин (за припущенням історика В. Габора, автором перекладу був історик і журналіст Михайло Семчишин). Характерно, що “Евеліна” вважається чи не найпопулярнішим твором Джойса серед перекладачів. Французька, італійська, словацька та російська джойсіани розпочалися 3 перекладів саме цього твору. Популярність "Евеліни" почасти пояснюється стилістичною й тематичною простотою: історію про звичайну дівчину з Ірландії, яка мріяла про щасливе життя закордоном, було написано простою (як для Джойса) мовою.

Отже, перші українські переклади оповідань збірки “Дублінці”, виконані окремими перекладачами-аматорами, містили чимало помилок - i змістових, i стилістичних. Приміром, М. Семчишин та I. Черкавський неправильно переклали рядки, що пояснювали причини страху Евелін перед батьком: When they were growing up he had never gone for her, like he used to go for Harry and Ernest, because she was a girl; but latterly he had begun to threaten her and say what he would do to her only for her dead mother's sake [12, с. 31]. Фразове дієслово to go for має кілька значень, одне з яких - “нападати на когось, завдавати фізичної шкоди” [7]. У перекладі І. Черкавського батько “Евеліни ніколи не інтересувався нею так, як Гарри'єм чи Ернестом, бо вона була дівчиною” [4, с. 278]; у перекладі М. Семчишина - батько “більше любив Ернеста і Гаррі, ніж іiі - дівчинку” [5, с. 105].

Ранні переклади містили численні стилістичні неоковирності та буквалізми: “те доводило іiі до биття серця / навіть з його причини діставала биття серця" (that had given her the palpitations), “ій грозила небезпека батькового побиття” (she felt herself in danger of her father's violence), корабельний хлопецьь (deckboy) тошьо. Деякі абзаци були пропущені. Перекладачі, зокрема М. Семчишин, зазвичай використовували стратегії одомашнення для перекладу імен та культурно-історичних алюзій. Відтак, жіночі прізвища Miss Hill, Miss Gavan M. Семчишин переклав із використанням присвійного суфікса -ов (наприклад, Пані Гілльова, Пані Гованова), підкресливши підпорядкованість жінки чоловікові, а саме батькові. 
Зважаючи на вищезгадані особливості ранніх перекладів оповідань Джойса, а також територіальні й мовні обмеження (переклади публікувалися в місцевих газетах заходу України, які були недоступні для читачів із Наддніпрянщини), потреба в нових перекладах була очевидною. Однак починаючи 3 30-х років 20 століття, розвиток української перекладної літератури й зокрема рецепція творчості Джойса призупинилися внаслідок сталінських репресій, спрямованих на винищення української інтелігенції.

На початку 60-х років - у період послаблення цензури після смерті Йосипа Сталіна - літературний процес почав помалу відновлюватися. Втім, переклади творів “буржуазної” літератури суворо контролювалася комуністичною партією. Позиції перекладачів були слабкими, їхні імена часто не друкувалися. Незважаючи на це, Джойса продовжували перекладати, часом супроводжуючи переклади критичними матеріалами пропагандистського спрямування. 1966 рік став знаковим для прихильників Джойса і для української літературної полісистеми загалом, адже на сторінках журналу "Всесвіт" було опубліковано фрагменти роману "Улісс" у перекладі Олександра Тереха за редакцією Григорія Кочура. Результати співпраці Тереха і Кочура заклали основу повного перекладу роману, який було видано завдяки зусиллям перекладача Олександра Мокровольського і видавництва Жупанського у 2015 році.

Одночасно не припинялася робота над перекладом “Дублінців”. У 1972 році оповідання "Пансіон” і “Евелін” з'явилися на сторінках журналу “Вітчизна" в перекладі Ярослава Стельмаха і Андрія Костецького. Як бачимо, журнали та альманахи стали основною платформою для поширення творчості Джойса. Ані романи, ані збірка оповідань не були перекладені повністю до часів незалежності почасти через цензурні обмеження.

Упродовж 2000-2007 рр. на сторінках журналу “Всесвіт" з'явилися переклади 9 з 15 оповідань збірки “Дублінці”, виконані перекладачем і українським джойсознавцем Еллою Гончаренко та істориком Романом Скакуном. Хоч їхні переклади публікувалися паралельно, обидва перекладачі працювали індивідуально і не підтримували зв'язок один 3 одним. Натомість, повний переклад збірки оповідань Джойса, виданий у 2017 році, з'явився в результаті співпраці перекладачів Бориса Превіра й Максима Ларченка. Цікаво, що збірка з'явилася і завдяки самим читачам, які отримали змогу фінансово підтримати публікацію перекладу в видавництві “Komubook”. Діяльність "Komubook" базується на принципі crowd publishing, тобто публікації книжок на кошти, зібрані читачами.

Вінтерв'юз авторкою статті Ларченко і Превір розповіли, що переклад “Дублінців” був їхньою власною ініціативою. Спочатку перекладачі планували зробити збірку оповідань Джойса пілотним проектом свого власного видавництва. За словами перекладачів, вибір твору був зумовлений двома чинниками: 1) відсутністю його на ринку українських перекладів; 2) відсутністю необхідності купувати права на видання твору українською мовою. Співпраця перекладачів відбувалась у такий спосіб: Борис Превір переклав оповідання під парними номерами (2, 4, 6 тощо), а Максим Ларченко - під непарними. Єдиним винятком стала фінальна новела “Мертві” (“The Dead”), над 
перекладом якої перекладачі працювали разом. Говорячи про особливості спільної роботи перекладачів, Борис Превір зазначає, що наявність “додаткової голови" суттєво прискорює процес перекладу і дозволяє уникнути помилок, які погіршують кінцевий результат. До того ж, перекладачі стверджують, що велику частку підготовки якісного перекладу оповідань Джойса зайняла пошуково-дослідницька робота. Для адекватного відтворення культурних та історичних алюзій перекладачі повсякчас читали тематичні статті, коментарі, консультувалися на ірландських інтернет-форумах. Крім того, перекладачі заглядали в російські переклади оповідань, але 3 попередніми українськими перекладами Романа Скакуна й Елли Гончаренко не ознайомлювалися, щоб уникнути прямого впливу.

Отже, переклади, опубліковані в другій половині XX століття й за часів Незалежності, якісно відрізняються від попередніх. По-перше, перекладачі не пропускали речень, фраз та абзаців, що було характерно для ранніх перекладів. Подруге, було виправлено численні стилістичні й змістові помилки, що траплялися в перекладах оповідання “Евеліна” 20-30-х років. Незграбні конструкції на кшталт “те доводило іï до биття серця" (пер. Черкавського) i “а навіть його причини діставала биття серця” (пер. Семчишина) було замінено на милозвучніші “і навіть на згадку про нього [батька - M. Б.] починає тремтіти” (пер. Стельмаха й Костецького); “від цього жаху в неї так іноді калатає серце" (пер. Гончаренко); “саме тому іiї серце тіпається" (пер. Превіра й Ларченка). Перекладачі також правильно інтерпретували фразове дієслово to go for, обравши відповідне до контексту значення: “він ніколи не бив ії так, як бив Гаррі та Ернеста” (пер. Гончаренко), “він ніколи не лупцював ії так, як Гаррі й Ернеста” (пер. Превіра й Ларченка). Цікавий відповідник запропонували Стельмах і Костецький - "раніше батько не займав її, як Гаррі та Ернста”. Українське дієслово “займати” також має багато значень, одне $з$ яких - "чіплятися, ображати, викликати на сварку, нападати” [7, с. 133]. Загалом вищезгаданим перекладам Стельмаха й Костецького притаманне використання вставних слів, прислівників, прикметників, відсутніх в оригіналі, але підхожим за змістом.

Переклади оповідань, опубліковані в 2000-х роках, рясніють примітками та пояснювальними коментарями, причому щопізніший переклад, то більше приміток використано, зокрема для відтворення культурно-історичних алюзій, ірландських реалій та іншомовних вкраплень. Здебільшого Ларченко і Превір використовують транскрипцію й транслітерацію для відтворення вищезгаданих стилістичних засобів; Гончаренко і Скакун здебільшого звертаються до пояснювального перекладу. Наприклад, згадані в оповіданні “Земля” barmbracks перекладено як “солодкі пироги” у версії Гончаренко й “бармбреки” у версії Ларченка й Превіра. Так само іменник swaddlers (зневажливе прізвисько для протестантів у католицькій Ірландіi) перекладено описово (“святенник”) у версії Романа Скакуна і транслітеровано у версії Ларченка і Превіра (“сводлери”). В обох випадках у коментарях подається історична довідка. Отже, переклади оповідань Джойса, опубліковані на початку 2000-х, відповідають правилам сучасного українського правопису. 3 іншого боку, молоді перекладачі Ларченко і Превір обрали сміливішу стратегію: хоча запозичення i велика кількість коментарів дещо ускладнювали структуру тексту, читачі 
отримали змогу сповна познайомитися з особливостями суспільного життя Ірландії ХХ століття.

Автобіографічний роман Джойса “Портрет митця замолоду”, вперше опублікований у США в 1916 році, розповідає історію фізичного, духовного та інтелектуального дорослішання Стівена Дедала - одного з головних героїв роману “Улісс". Ідейна основа твору - переоцінка молодою особистістю попередніх уявлень про соціум, релігію та сім'ю, а також відсутність творчої свободи для митця в Ірландії XX сторіччя. Уперше фрагменти роману з'явилися на сторінках “Всесвіту”в 1975 році в перекладі Ярослава Стельмаха - дитячого письменника й драматурга, сина українського письменника Михайла Стельмаха. За словами перекладача, видання "Портрета...” супроводжувалося деякими труднощами. Третю главу роману не було перекладено взагалі, декілька фрагментів пропущено. У 2005 році Мар'яна Прокопович завершила працю Стельмаха, і видавництво ВНТЛ-класика опублікувало повний переклад "Портрета...”.

У бесіді з авторкою статті Мар'яна Прокопович стверджує, що вона лише частково використала переклад Стельмаха, значно його змінивши. За словами перекладачки, їі підхід до тексту був іншим. Крім того, Прокопович не спілкувалася зі Стельмахом за його життя й не читала творів його авторства. Попри все, цей випадок також можна вважати окремим прикладом співпраці перекладачів, у якому живе спілкування (як у тандемі Ларченка і Превіра) замінилося спілкуванням через текст, залишений одним перекладачем на умовне “доопрацювання” іншому. Опрацьовуючи фрагменти, перекладені Стельмахом, Мар'яна Прокопович виправляла стилістичні та змістові помилки, заповнювала пропущені місця, а в окремих випадках майже повністю використовувала його переклад. До прикладу, епізод із роздумами Стівена про “чудернацький пам'ятник народному ірландському поетові” відтворено в обох варіантах майже ідентично. Єдина різниця - супровідний коментар, поданий приміткою. Якщо Стельмах покликається на Олівера Голдсміта як джерело алюзії Джойса, то Прокопович стверджує, що “народним поетом” був Томас Мур. Ї̈̈ версія підтверджується відомим джойсознавцем Доном Гіффордом, який склав коментований путівник по творчості Джойса [10, с. 231]. 3 іншого боку, і Прокопович, і Стельмах зазвичай використовують однакову стратегію відтворення іншомовних вкраплень, а саме збереження оригінального елементу з перекладом, поданим приміткою. Загалом обидва перекладачі працювали 3 текстом емпатично, підшукуючи належні відтінки значень, розгадуючи Джойсові мовні ігри та інтертекстуальні головоломки. Отже, поява цього блискучого взірця психологічної прози, приправленого вишуканою мовою й неординарним сюжетом, неодмінно збагатила українську літературну полісистему.

Часто обділене увагою критиків есе “Джакомо Джойс" - це посмертно опублікований автобіографічний твір письменника, що, за припущеннями, був чернеткою його великих романів “Улісс" i “Портрет...”. Перший переклад есе вийшов друком у 2004 році завдяки праці літературознавця й перекладача Ростислава Доценка. Долі Джеймса Джойса та українського дослідника його творчості були дуже схожі між собою. Обидва постраждали від державної цензури; обидва жили у вигнанні. Однак якщо Джойс попрямував закордон у пошуках натхнення самостійно, Доценко було 
звинувачено в “антирадянській пропаганді”, “націоналізмі” і, як наслідок, заслано в один із таборів ГУЛАГу в Мордовії. Ірландія посідала особливе місце серед наукових і перекладацьких інтересів Доценка. У 1980-1990-ті перекладач написав кілька статей, присвячених розвитку новелістики в Ірландії й зокрема творчості Джойса. У статті “Далека і близька Ірландія” (1993) Доценко зазначав, що рецепція ірландської літератури в Україні значно обмежувалася партією, а згадувати про Великий голод 1840-х років, утиски ірландської мови і зневагу до ірландських національних традицій було вкрай небажано.

Сама лише назва есе “Джакомо Джойс" натякає на його автобіографічність, адже Джакомо - це італійська варіація імені письменника. Есе відкриває читачеві потаємні переживання ліричного героя, закоханого у свою молоду ученицю. Уривки спогадів, думок і фраз, сказаних і продуманих італійською, англійською та латиною, становлять композиційну основу сюжету. У багатомовності цього есе розкривається мовна особистість Джойса: народжений в Ірландії, Джойс із дитинства чув гіберноанглійську, вивчав латину і грецьку, жив у Франції та Італії, постійно користуючись національними мовами цих країн. Тож, основним завданням перекладача було відтворення мовностилістичної “соковитості” цього твору. Останнє було неможливим без спілкування перекладача з автором через його текст-автопортрет.

“Італійськість” Доценкового перекладу есе не поступається Джойсовій. Усі речення і фрази італійською мовою, що повсякчас з'являлися в думках головного героя, було збережено в перекладі, а їхнє значення подано коментарем українською мовою. Відповідно, Доценко відтворив мовну неоднорідність вихідного тексту i, водночас, надав читачеві можливість подолати можливий мовний бар'єр для максимально адекватного розуміння твору Джойса.

Яскрава мовна палітра Джойсового ідіостилю, що сповна розкривається в “Джакомо...", варта особливої уваги. Характерною ознакою всіх творів Джойса й цього есе зокрема є використання авторських епітетів. Описуючи образ коханої, письменник зауважує найтонші відтінки кольорів: streaks of egg yolk yellow, rancid yellow humour, grey whey hued shadows, creamy summer haze [12, с. 2]. В українському перекладі епітети звучать не менш виразно головно завдяки алітерації, створеній майстерним поєднанням слів: “пасма жовткової жовтизни”, “прогіркло жовчний гумор”, “сірувато-сизі тіні”, “кремовим літнім мревом” [2]. Тож, Ростиславові Доценку вдалося не лише передати мовну неоднорідність оригінального есе шляхом збереження іноземних вкраплень, але й відтворити стилістичну досконалість Джойсового стилю засобами цільової мови.

Висновки. Отже, рецепція прозових творів Джеймса Джойса в Україні пережила декілька етапів - від перших спроб перекладачів-аматорів до професійних перекладів монументальних робіт письменника. Аналіз повторних перекладів свідчить про тенденцію до покращення їхньої якості, збільшення кількості коментарів і пояснень, а також запозичень. Праця перекладацьких тандемів, що передбачає безпосереднє спілкування перекладачів або співпрацю живого й померлого перекладача через текст, свідчить про успішність такої форми організації процесу перекладу, якщо мова йде про складні багатокомпонентні тексти. 
До того ж, в останні десятиліття переклади творів Джойса зацікавили не лише літературні журнали, але й видавництва. Про цікавість читацької аудиторії свідчить публікація збірки оповідань “Дублінці” й повторне видання роману “Портрет митця замолоду” у видавництві “Кomubook", проспонсовані самими читачами. Утім, власне критики українських перекладів творів Джойса досі бракує. Авторка статті висловлює сподівання, що умови для подальших публікацій творів Джойса й надалі будуть сприятливими, а інтерес читачів, письменників і власне перекладачів до невичерпного потенціалу модерністської літератури лише ростиме.

\section{СПИСОК ВИКОРИСТАНОЇ ЛІТЕРАТУРИ}

1. Гадамер Г. Г. Істина і метод. Том І. Основи філософської герменевтики / пер. 3 нім. О. Мокровольського. Київ : Юніверс, 2000. 464 с.

2. Джойс Д. Джакомо Джойс / пер. Р. Доценка. Бібліотека украӥнської літератур URL: http://www.ukrlib.com.ua/world/printit.php?tid=87.

3. Джойс Дж. Дублінці / пер. М. Ларченка і Б. Превіра. Київ : Комубук, 2017. 238 с.

4. Джойс Дж. Евелін / пер. І. Черкавського. Дзвони. 1933. Ч. 6/7. С. 277-280.

5. Джойс Дж. Евеліна / пер. М. Семчишина. Назустріч. 1936. Ч. 105, 106. С. 105.

6. Павличко С. Дискурс модернізму в українській літературі : монографія. 2-ге вид. Київ : Либідь, 1999. 447 с.

7. Словник української мови [в 11 т.]. Т. 3. Редкол.: І. К. Білодід [та ін.]. ред. А. А. Бурячок, Г. М. Гнатюк. Київ : Наукова думка, 1973. 744 с.

8. Abrams M. H. A Glossary of Literary Terms. Seventh Edition. Boston : Heinle \& Heinle, 1999. $366 \mathrm{p}$.

9. Gentzler E. Translation and Rewriting in the Age of Post-Translation Studies. New York : Routledge, 2017. $260 \mathrm{p}$.

10. Gifford D. Joyce Annotated. Notes for Dubliners and A Portrait of the Artist As a Young Man. Berkeley and Los Angeles : University of California Press, 1982. 308 p.

11. Joyce J. Dubliners. Richmond : Alma Books, 2012. 246 p.

12. Joyce J. Giacomo Joyce. Postarchive. URL: https://postarchive.files.wordpress. com/2015/03/joyce-james-giacomo-joyce-faber-faber-1968.pdf.

13. Leernout G., W. Mierlo. The Reception of James Joyce in Europe. London and New York : Thoemmes Continuum, 2004. 354 p.

14. Mecsnóber M. James Joyce and "Eastern Europe". Joycean Unions: Post-Millennial Essays from East to West. 2015. № 22. P. 1-31.

15. Online Macmillan Dictionary. URL: https://www.macmillandictionary.com.

16. Pym A. Method in Translation History. Manchester : St. Jerome, 1998. 220 p.

17. Rundle C. History through a Translation Perspective. Between Cultures and Texts. Itineraries in Translation History / ed. by A. Chalvin, A. Lange et. al. Frankfurt am Main : Peter Lang, 2011. P. 33-43. 


\section{REFERENCES}

1. Gadamer H. G. Istyna i metod [Truth and Method]. Tom I. Osnovy filosofskoyi hermenevtyky [Fundamentals of Philosophical Hermeneutics] / per. z nim. O. Mokrovolskoho. Kyiv : Univers, 2000. 464 s.

2. Joyce J. Giacomo Joyce / per. R. Dotsenka. Biblioteka ukrainskoi literatury. URL: http:// www.ukrlib.com.ua/world/printit.php?tid=87.

3. Joyce J. Dublintsi [Dubliners] / per. M. Larchenka i B. Previra. Kyiv : Komubuk, 2017. $238 \mathrm{~s}$.

4. Joyce J. Evelin [Eveline] / per. I. Cherkavskoho. Dzvony. 1933. Ch. 6/7. S.277-280.

5. Joyce J. Evelina [Eveline] / per. M. Semchysyna. Nazustrich. 1936. Ch. 105, 106. S. 105.

6. Pavlychko S. Dyskurs modernism v ukrainskiy literaturi [Modernist discourse in the Ukrainian literature]. Monografia. 2-he vyd. Kyiv : Lybid, 1999. $447 \mathrm{s.}$

7. Slovnyk ukrayinskoyi movy [v 11 T.] [Dictionary of the Ukrainian language [in 11 vol.]. T. 3. Redkol.: I. K. Bilodid [ta in.]. red. A. A. Buriachok, H. M. Hnatiuk. Kyiv : Naukova dumka, $1973.744 \mathrm{c}$.

8. Abrams M. H. A Glossary of Literary Terms. Seventh Edition. Boston : Heinle \& Heinle, $1999.366 \mathrm{p}$.

9. Gentzler E. Translation and Rewriting in the Age of Post-Translation Studies. New York : Routledge, 2017. $260 \mathrm{p}$.

10. Gifford D. Joyce Annotated. Notes for Dubliners and A Portrait of the Artist As a Young Man. Berkeley and Los Angeles : University of California Press, 1982. 308 p.

11. Joyce J. Dubliners. Richmond: Alma Books, 2012. 246 p.

12. Joyce J. Giacomo Joyce. Postarchive. URL: https://postarchive.files.wordpress. com/2015/03/joyce-james-giacomo-joyce-faber-faber-1968.pdf.

13. Leernout G., W. Mierlo. The Reception of James Joyce in Europe. London and New York : Thoemmes Continuum, 2004. 354 p.

14. Mecsnóber M. James Joyce and "Eastern Europe". Joycean Unions : Post-Millennial Essays from East to West. 2015. № 22. P. 1-31.

15. Online Macmillan Dictionary. URL: https://www.macmillandictionary.com.

16. Pym A. Method in Translation History. Manchester : St. Jerome, 1998. 220 p.

17. Rundle C. History through a Translation Perspective. Between Cultures and Texts. Itineraries in Translation History / ed. by A. Chalvin, A. Lange et. al. Frankfurt am Main : Peter Lang, 2011. P. 33-43. 


\title{
DYNAMICS OF RECEPTION OF JAMES JOYCE'S PROSE IN UKRAINE: SOCIOCULTURAL CONDITIONS AND TRANSLATIONAL CHOICES
}

\author{
Mariia Bondarenko
}

\author{
Ivan Franko National University of Lviv, \\ 1, Universytetska Str., Lviv, Ukraine, 79000 \\ mariya.bondarenko@lnu.edu.ua
}

The article elicits the reception of prose works by the Irish writer James Joyce in Ukraine since 1920s till present. Particularly, the article attempts to investigate the reasons for (non)translations of the writers works in Ukraine during a certain historical period and their probable influence on the development of modernism in Ukraine. To achieve this aim, the general social and cultural context was studied, and critical articles, reviews and translators's commentaries were analyzed. Additionally, in order to study individual translators' motivations, peculiarities of the translation process and translators' cooperation, the living translators were interviewed. As a result, two types of translator's tandems were studied: cooperation between living translators and the one based on the communication between the living translator and the text left by the deceased translator. The particular attention is focused on rendering cultural and historical allusions and lingual experiments as a part of Joyce's artistic method shaping the structure of Dubliners, A Portrait of the Artist as a Young Man and Giacomo Joyce. The study has shown that early reception of Joyce's prose (1920-30s) started with the publication of critical articles in West Ukrainian periodicals; first translations of short stories were characterized by numerous stylistic and semantic mistakes. The lack of supplementary commentaries and inaccessibility of foreign criticism, as well as ideological pressures, hindered the reception process. Due to the fact that first translations of Joyce's prose were territorially and linguistically restricted, the need for the new ones was obvious. Later translations of Joyce's short stories (1970s-2017) were marked by interesting tendency: each subsequent translation involved more foreignizing techniques than previous one (e.g., cultural allusions were transliterated rather than translated; foreign language inclusions were preserved; more commentaries and footnotes were provided). The analysis of the essay Giacomo Joyce translated by R. Dotsenko has demonstrated that translator managed to re-create Joyce's artistic creativity by means of the Ukrainian language.

Key words: literary translation, reception, multilingualism, allusion, Joyce, modernism, "Dubliners". 